\title{
A Sustainable Zimbabwe University - Industry Collaboration Framework
}

\author{
Stanley Murairwa \\ Africa University, Mutare, Zimbabwe
}

\begin{abstract}
The collaboration between a knowledge hub and a product incubator is increasingly perceived as a vehicle to enhance innovation and business incubation through knowledge and technology exchange. This is evidenced by a significant increase in researches that investigate the collaboration phenomenon from different perspectives. However, the body of knowledge is still fragmented and lacking an efficient comprehensive view that can widely be considered as the engine of economic growth. A sample of volunteered (Murairwa, 2015) 12 knowledge hubs and 60 product incubators was selected. The research employed systematic procedures to review the literature and analyse researchers' perspectives on the collaboration between industry and universities. The research designed a questionnaire with closed and a few open-ended questions and collected data from volunteering knowledge hubs and incubators. The data was analysed in Statistical Package of Social Sciences (SPSS). The research discovered key aspects underpinning the collaboration theory. These aspects were integrated into an overarching pragmatic knowledge hub and product incubator collaboration (PKHPIC) framework that can provide a substantial contribution to the understanding of the university - industry collaboration and literature in the research area.
\end{abstract}

Keywords: University-Industry Collaboration, Knowledge Hub, Product Incubator, Framework, Technology

JEL: I2, I21 - I26; O3, 031 - 038

Paper classification: Research paper

\section{INTRODUCTION}

$\mathrm{T}$ he importance of collaboration for knowledge exchange between a knowledge hub (university) and a product incubator (industry) has long been widely recognised as a significant economic development phenomenon. The knowledge and technology exchange was identified as the major objective of collaborating by Ankrah and Al-Tabbaa (2015) and Birchall and Shanaron (2006). The efficiency of the economies and innovation levels of industrialised countries are due to production of knowledge and its use in industries, thereby achieving competitive advantages in the global markets (Mascarenhas, Ferreira, \& Marques, 2018). Thus, the collaboration between a knowledge hub and a product incubator can facilitate knowledge transfer; stimulate the production of new knowledge and technology (Freitas, Marques, \& Silva, 2013; Enkel, Gaddmann, \& Cesbrough, 2009); alleviate the commercialisation of academic knowledge and patenting and licensing of inventions as well as academic entrepreneurship (Perkmann, et al., 2013). Zimbabwe lags behind in terms of scientific and technological capabilities despite having technology biased universities (Ngwenya, 2018) and eminent educational policies. The world over, universities are recognised as hubs for discovering knowledge while companies incubate high quality and competitive products.

Although the potential for impressive outcomes is plentiful, the collaboration between a knowledge hub and a product incubator is fragmented and inefficient, a fact raised by Ankrah and Al-Tabbaa (2015). The lack of collaboration highly impacts on product incubators' capabilities, competitiveness and output quality and the country's economy. The statistics from Zimbabwe's Ministry of Higher and Tertiary Education, Innovation, Science and Technology Development indicate that approximately 30000 students graduate annually from the country's tertiary institutions (Moyo, 2016). According to Fynn (2020), a study shows that university graduates may remain unemployed for up to a year. König and Ribarić (2019) stated that there was a misunderstanding between knowledge hubs and incubators on the roles they play as knowledge hubs believe that industries do not fully appreciate the graduates' acquired knowledge and on the other hand, incubators question the work readiness of these graduates. For the first quarter of 2019, recent figures from Statistics South Africa reveal that the unemployment rate of graduates was pegged at $31 \%$ (Fynn, 2020). According to Robert (2019), the education and job mismatch are common at the modern societies' labour market. These are evidence that there is mismatch between what knowledge hubs offer and what employers need and expect. The mismatch between the expectations of product incubators and what the knowledge hubs churn out has seen many graduates failing to secure employment so much that the rate of unemployment in Zimbabwe was at ninety percent (Marr, 2017).

On the other hand, the product incubators are also facing viability constraints with only $20 \%$ operating below $50 \%$ capacity, an eventuality that can be attributed in part to lack of collaboration. The companies' production capacities decreased from $48.20 \%$ in 2018 to $34.30 \%$ in 2019 (Chideme, 2019). These statistics show that industries in Zimbabwe are not benefitting from the knowledge and technologies that are discovered by universities, thus, making universities irrelevant to industries. In Zimbabwe, the Ministry of Higher and Tertiary Education, Innovation, Science and Technology Development popularised the idea of technology, innovation 
and service hubs (TISHs), popularly known as Education 5.0, at universities in order to champion home grown business scientific research, idea generation, innovation and incubation. The mooted idea, though noble, has not attracted much interest from significant stakeholders such as preschool, primary and secondary education institutions, sponsors and industries. The absence of a buy-in from industries could be attributed to limited consultation in the design and implementation of the refreshing noble enterprise.

While efforts have been made such as the establishment of the Zimbabwe Manpower Development Fund (ZIMDEF) and the one-year student industrial attachment, the key stakeholders need to participate more in order for Zimbabwe to realise additional benefits from the collaboration phenomenon, which has been fully developed in most developed and developing countries. The collaboration between universities and industry remains a critical area of concern (Rybnicek \& Konigsgruber, 2019) and the argument was echoed by Ngwenya (2018) who argued that Zimbabwe lacked a clear policy on the collaboration between universities and industry. According to Sherwood, Butts and Kacar (2004), the impact of a successful implementation of the universities and industry collaboration remains a key question that begs for research answers. The tasks \{teaching, research, community service, business incubation and innovation (Murairwa, 2018)\} of the knowledge hubs have evolved through time from merely teaching (Level 2.0) to industrialisation (Level 5.0). The evolution of the tasks demands more participation of all relevant stakeholders. This research deliberately used the terms "knowledge hub" to refer to a university and "product incubator" to refer to industry. The term "Col-Lab-Oration" is a combination of three words, namely, Col meaning gap, Lab meaning scientific research workplace and Oration meaning formal address of an audience. Thus, collaboration is a formal practice of working together of the knowledge hub and product incubator in order to address real life problems that affect people and processes through scientific researches. The research objectives were to explore the various collaboration forms, areas and benefits and suggest a sustainable framework that can facilitate a successful collaboration between a knowledge hub and a product incubator.

\section{LITERATURE REVIEW}

Over the years, the collaborations between university and industry have led to new discoveries (Gann, Montresor, \& Eisenberg, 2018) According to Abuja et al. (2019), universities were not comfortable with the collaboration because they viewed it as restricting their academic freedom. A number of researchers investigated the various forms of collaboration between universities and industry (Barringer \& Harrison, 2000) but failed to agree on the definitions and distinctions (Bruneel, D'esteb, \& Salter, 2010). Thus, the question is "What are the various forms of association between a knowledge hub and a product incubator?" Plewa, Korff, Johnson, Macpherson and Rampersad (2013) examined pre-collaboration, establishment, engagement, advancement and latent university-industry collaboration phases. Shizha and Kariwo (2011) argued that Zimbabwe universities are ideal to deal with the economic challenges facing the country because they are always looking at exploring innovative shortterm an'd medium-term mechanisms of improving various science, technology, knowledge and skills. This contradicts Ncube (2017) who stated that African universities were churning out useless graduates. Therefore, the collaborations between industries and universities are important for innovation and knowledge exchange (Morisson \& Pattinson, 2020; Rybnicek \& Konigsgruber, 2019). This will result in universities producing graduates with the minimum requirements of industries. Perkmann and Walsh (2019) found that most conducted researches focused on the effects of the links between universities and industry on innovation specific variables such as patents or innovativeness, with organisational dynamics of these relationships remaining under-researched. Thus, the question is "What are the relationships between the tasks that are performed by the knowledge hub and product incubator?" The common objectives of the university and industry (Ivascu, Cirjaliu, \& Draghici, 2016) are shown in Table 1.

Table 1: Common Objectives of the University and Industry

\begin{tabular}{|c|c|c|}
\hline University & Common & Industry \\
\hline Public Mission & Creating Value for Society & Shareholder \\
\hline Publications & Reputation & Revenue \\
\hline Project Research & Research & Practical Research \\
\hline Theoretical Drivers & Science Driven & Results Driven \\
\hline Shared Resources & Competitiveness & Private Resources \\
\hline Sharing Results & Value & Retain Results \\
\hline Creating Knowledge & Sharing Knowledge & Capturing Knowledge \\
\hline Open Source & Collaborative Innovation & Private Source \\
\hline Investigator Needs & Patient Needs & Market Needs \\
\hline Education & Exchange Know-How & Retain Know-How \\
\hline
\end{tabular}

Source: adapted from Ivascu, Cirjaliu and Draghici (2016)

Table 1 shows ten similar activities that are performed by both the knowledge hub and product incubator. The common objectives are the level of comparison of the tasks that are performed by the knowledge hub and product incubator. Sherwood et al. (2004) investigated the knowledge transfer between university and industry and formulated a knowledge chain. According to Liew, Tengku Shahdan and Lim (2012), the success of the collaboration between a knowledge hub and a product incubator depends on the ability to identify the common tasks of both institutions. Liew et al. (2012) further studied strategic and tactical approaches and found the areas of collaboration between universities and industry. Andrade, Fernandes and Tereso (2016) identified the areas of benefit from collaboration. Thus, the question is "Which areas can the knowledge hub and product incubator collaborate on?" Salleh and Omar (2013) offered a university and industry collaboration model that focuses on the interaction of 
industry, Government and university. On the other hand, Kaklauskas et al. (2018) and Rast, Khabhiri and Senin (2012) suggested an evaluation framework for assessing the collaboration mechanisms. NAP (2018) identified the features of a successful collaboration between industry and university. Thus, the question is "Which framework can facilitate a successful and sustainable collaboration between a knowledge hub and a product incubator?" According to O'Shea et al. (2008), Phan and Siegel (2006) and Rothaermel et al. (2007), the commercialisation of university knowledge has attracted attention of researchers and policy makers. Ankrah and AlTabbaa's (2015) research applied equal focus of both the university and industry perspectives. The mechanisms of collaboration of companies include resources, governance, communication and evaluation (DSDL, 2019). Awasthy, Flint, Sankarnarayana and Jones (2020) proposed a framework for enhancing the effectiveness of the collaboration between university and industry. Industry is the most influential stakeholder in university education (Tsitskari, Goudas, Tsalouchou, \& Michalopoulou, 2017).

\section{Research Gap}

A number of researches have been conducted especially on the framework for evaluating the performance of the collaboration between universities and industry (Kaklauskas, et al., 2018; Ivascu, Cirjaliu, \& Draghici, 2016; Salleha \& Omara, 2013; Rast, Khabiria, \& Senina, 2012; Liew, Tengku Shahdan, \& Lim, 2012) as advocated for by Birchall and Chanaron (2006). According to Zhao, Brostron and Cai (2020), Perkmann and Sobrero (2013), O'Shea et al. (2008), Rothaermel et al. (2007) and Phan and Siegel (2006), the relationship between universities and industry attracted the attention of academic researchers and policy makers. However, the body of knowledge is still regarded as disconnected and deficient of a comprehensive phenomenon (Ankrah \& AL-Tabbaa, 2015). The Zimbabwe economy is currently experiencing turbulent sailing and all its components (such as knowledge hubs and product incubators) are not responding to the calls to address the challenges. Ankrah and Al-Tabbaa (2015) stated that the collaboration of the economic components was viewed as the engine of research and innovation through knowledge exchange. The advocacy for coaction of the economic components for full utilisation of the available resources is still to bear a sustainable and globally acceptable collaboration framework between a knowledge hub and a product incubator.

\section{METHODOLOGY}

The research applied a quantitative research method in which quantitative data was collected from the literature and participants. The research conducted a literature survey in order to understand in depth the collaboration between a knowledge hub and a product incubator and to collect data for analysis. The interaction of the research variables is shown in Figure 1.

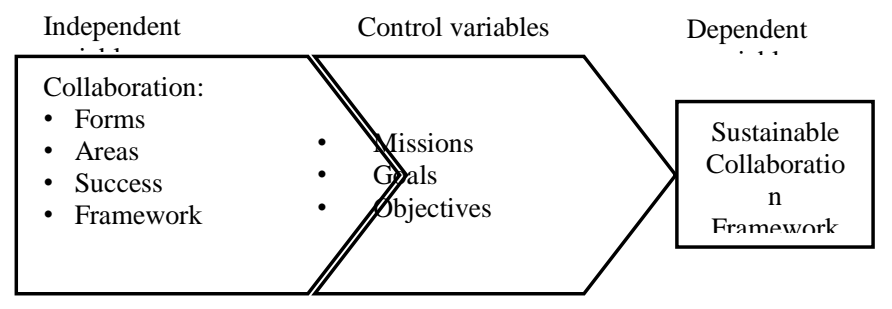

Figure 1: Interaction of the Research Variables

The population was made up of 72 Harare product incubators in Lytton and Southerton industrial areas and 24 registered knowledge hubs in Zimbabwe. A sample of volunteered (Murairwa, 2015) 12 knowledge hubs and 60 product incubators was selected. The research collected data from the participants using a distributed questionnaire. A questionnaire with closed and a few open-ended questions was designed. The researcher physically distributed the questionnaires to knowledge hubs and incubators. Convenience sampling was applied to select participates in the research. Thus, the availability and willingness to participate determined whether one was to be given a questionnaire or not. The researcher collected the completed questionnaires. The research applied quantitative techniques to analyse the gathered research data in SPSS.

\section{RESULTS AND DISCUSSIONS}

The research found that most knowledge hubs were signing collaboration memorandums of understanding with different product incubators in Zimbabwe. The management of the product incubators who participated in the survey indicated that they had held discussions with management of knowledge hubs in the past two years regarding collaborating in seminars and conferences (25\%), scientific research (23.18\%), competency training (20.31\%), consultancy (16.41\%), resources mobilisation and sharing $(9.90 \%)$, technology development $(2.86 \%)$ and knowledge transfer $(2.34 \%)$. The most popular collaborating areas were seminar and conference, research, training and consultancy. The results concur with the findings by Ivascu et al. (2016) on the common objectives of the knowledge hub and product incubator and Malairaja and Zawdie (2008) who found that $59.10 \%$ of the science park companies had links with knowledge hubs. Thus, the components of the Zimbabwe economy were realising the importance of collaborating, although, still at a lower level than expected. The research assessed the forms of collaboration between a knowledge hub and a product incubator. The data gathered was classified into two thematic groups, namely, collaboration forms (Figure 2) and partnership forms (Table 2). 


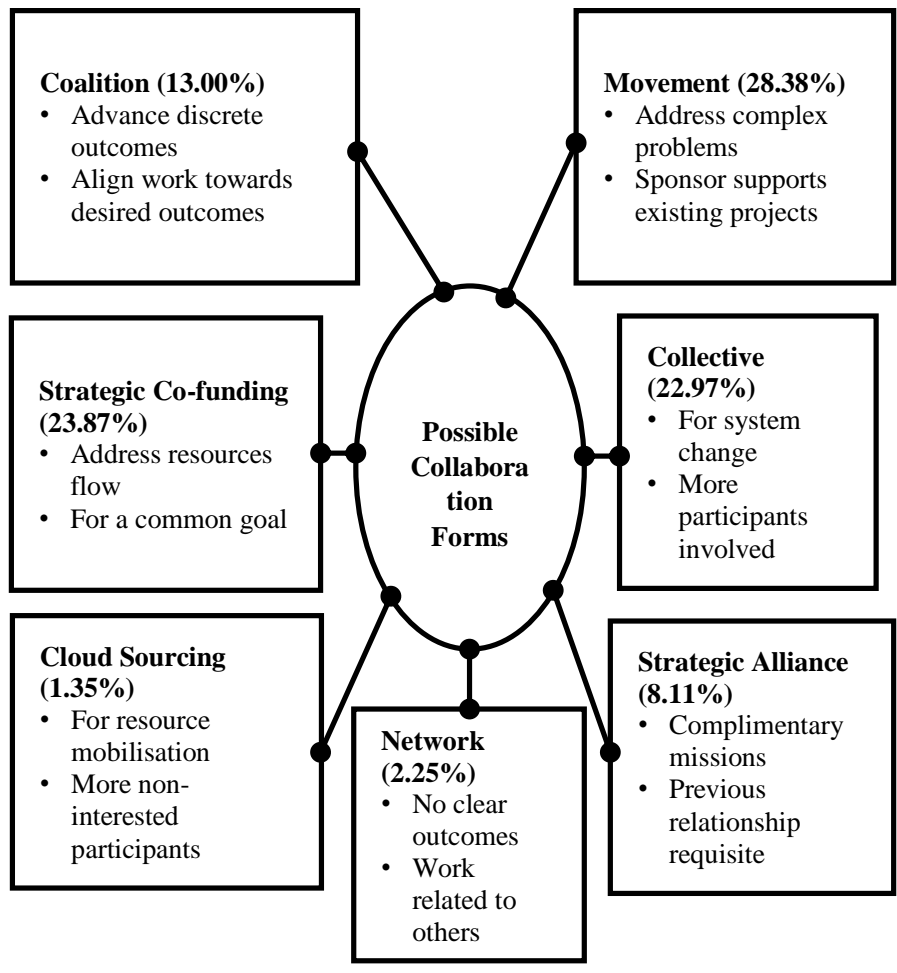

Figure 2: Collaboration Forms

Figure 2 presents the forms of collaboration that the knowledge hub and product incubator can enter depending on their missions, goals and objectives. The most popular collaboration forms in Zimbabwe were movement (28.38\%), strategic co-funding (23.87\%) and collective (22.97\%). These results concur with the research findings by McNabb and Swenson (2021), Laroui (2020), Dartington Service Design Lab (DSDL) (2019), Pop (2017), Ankrah and Al-Tabbaa (2015), Liew et al. (2012), Scearce (2011) and Bruneel, D'esteb and Salter (2010). The data analysis also revealed the possible partnership forms that can be entered into between a knowledge hub and a product incubator that are presented in Table 2.

Table 2: Possible Partnership Forms

\begin{tabular}{|c|c|c|c|}
\hline \multirow{2}{*}{$\begin{array}{c}\text { Partnership } \\
\text { Forms }\end{array}$} & Description & \multicolumn{2}{|c|}{ Liability } \\
\hline & Unlimited & Limited \\
\hline General & Management responsibility & $\checkmark$ & \\
\hline Limited & $\begin{array}{c}\text { Financial stake, no } \\
\text { management stake }\end{array}$ & & $\checkmark$ \\
\hline $\begin{array}{c}\text { Limited } \\
\text { Liability }\end{array}$ & $\begin{array}{c}\text { Enjoys limited partnership } \\
\text { liability }\end{array}$ & & $\checkmark$ \\
\hline Holding out & $\begin{array}{c}\text { Represented as a partner by } \\
\text { someone }\end{array}$ & $\checkmark$ & \\
\hline Active & $\begin{array}{c}\text { Participates in duties } \\
\text { regularly }\end{array}$ & $\checkmark$ & \\
\hline Minor & $\begin{array}{c}\text { Not entitled to take part in } \\
\text { business }\end{array}$ & & $\checkmark$ \\
\hline Silent & $\begin{array}{c}\text { No contribution to business } \\
\text { operation }\end{array}$ & $\checkmark$ & \\
\hline Secret & $\begin{array}{c}\text { Operates behind the } \\
\text { business scenes }\end{array}$ & $\checkmark$ & \\
\hline
\end{tabular}

\begin{tabular}{|c|c|c|c|}
\hline Proceeds & $\begin{array}{c}\text { Amount of responsibility } \\
\text { owned }\end{array}$ & $\checkmark$ & \\
\hline Support & $\begin{array}{c}\text { Assist in business } \\
\text { operations }\end{array}$ & & $\checkmark$ \\
\hline Community & $\begin{array}{c}\text { Addressing community } \\
\text { problems }\end{array}$ & & $\checkmark$ \\
\hline Outside & $\begin{array}{c}\text { Initiated from non- } \\
\text { participants }\end{array}$ & & $\checkmark$ \\
\hline
\end{tabular}

Table 2 shows the forms of partnerships that can be signed between a knowledge hub and a product incubator. The research classified the partnership forms into unlimited and limited reliabilities as presented in Table 2. The findings on the similarities of the tasks of the knowledge hub and product incubator are presented in the collaboration chain that is presented in Figure 3.

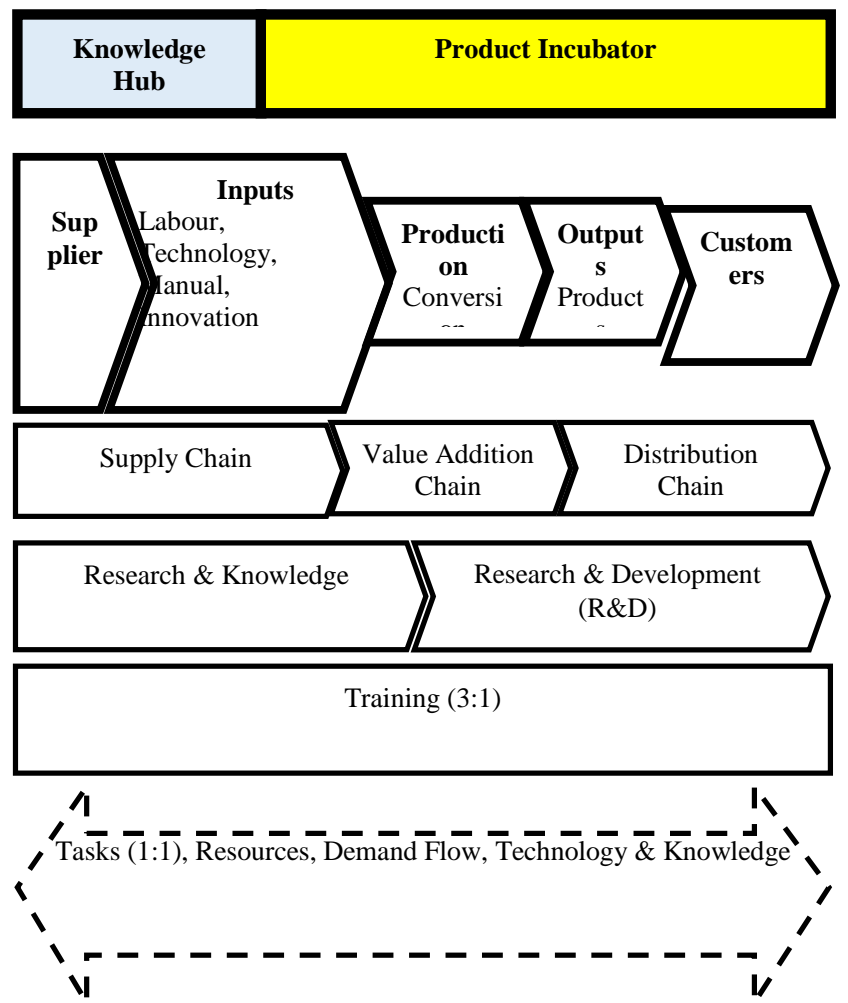

Key: Existing Proposed

Figure 3: Knowledge Hub and Product Incubator Tasks (KHPIT) Chain

Figure 3 shows that all the tasks that are performed by the knowledge hub (university) are also performed by the product incubator (industry). What may differ is the degree and rate of implementation. The comparison of the processes of the knowledge hub and product incubator highlighted the similarities of the tasks. The results are similar to Ivascu et al.'s (2016) common objectives between a knowledge hub and a product incubator and Sherwood et al.'s (2004) knowledge chain. The results indicate that the interaction of Zimbabwe's economic components had isolated operations plateaus with independent twinning of meagre resources that could be pulled together to maximise the output. Figure 3 also shows the proposed imminent interaction between a knowledge hub 
and a product incubator. The research explored the areas that the knowledge hub and product incubator can collaborate on and presented the results in Table 3.

Table 3: Knowledge Hub and Product Incubator Collaboration Areas

\begin{tabular}{|c|c|c|}
\hline Collaboration Area & Percent Response & Rank \\
\hline Resource Mobilisation & 15.21 & 1 \\
\hline Research & 12.28 & 2 \\
\hline Consultancy & 11.70 & 3 \\
\hline Community Service & 11.11 & 4 \\
\hline Innovation & 9.95 & 5 \\
\hline Business Incubation & 9.65 & 6 \\
\hline Systems Reliability Optimisation & 8.19 & 7 \\
\hline Crowdsourcing Projects & 7.60 & 8 \\
\hline Technology Development & 5.84 & 9 \\
\hline Skills Transfer & 4.39 & 10 \\
\hline Logistics Optimisation & 4.09 & 11 \\
\hline
\end{tabular}

Table 3 shows that the knowledge hub and product incubator can collaborate in resource mobilisation (15.21\%), research $(12.28 \%)$ \{market survey: expectations, perceptions and behaviour, graduate employability as conducted by Salleh and Omar (2013)\}, logistics optimisation (4.09\%) \{transportation, assignment and trans-shipment\}, consultancy (11.70\%) \{professional practice that gives expert advice\}, systems reliability optimisation $(8.19 \%)$ and crowd-sourcing projects $(7.60 \%)$ dobtaining work, information or opinions from a large group of people through internet, social media and smartphone applications $\}$. The results concur with the findings by König and Ribarić (2019), Nyström, Karltun, Keller and Gare (2018), Ankrah and Al-Tabbaa (2015), Rast et al. (2012) and Liew et al. (2012). The knowledge hub and product incubator collaboration research (KHPICR) model is presented in Figure 4.

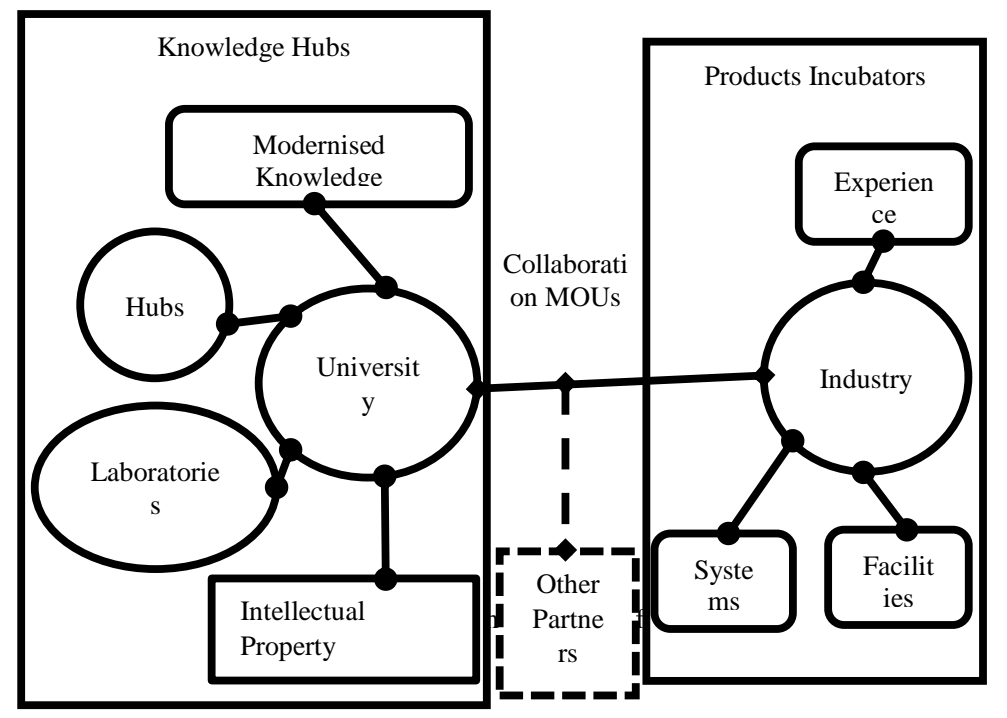

Figure 4: Knowledge Hub and Product Incubator Collaboration Research (KHPICR) Model
Figure 4 shows a general knowledge hub and product incubator collaboration research (KHPICR) model. The knowledge hubs form new advance theories and develop concepts from new innovation. The product incubators adopt the theories and incubate into new products. Therefore, the knowledge hub and product incubator should work together from the initial stage of discovery of theories to commissioning of the new products in order to reduce the number of failure of new businesses. The institutions in a collaboration benefit through knowledge transfer, generation and exchange, strategic marketing, additional funding and commercialisation of the research findings. Figure 4 also shows that researchers should focus on the collaboration between a knowledge hub (university) and a product incubator (industry) with any other partner coming in on a supporting role. The resources brought by each partner in a collaboration research are clearly shown in Figure 4. The results are similar to Salleh and Omar's (2013) collaboration model for a successful interaction between a knowledge hub and a product incubator and Rast et al.'s (2012) research framework. The open ended questions in the questionnaire gathered the specific benefits accrued by the knowledge hub and product incubator in a collaboration and these are presented in Table 4.

Table 4: Benefits of Collaborating

\begin{tabular}{|c|c|}
\hline Knowledge Hub & oduct incubator \\
\hline $\begin{array}{l}\text { - Opportunity to assess the economy's } \\
\text { needs. } \\
\text { - Professors and students are exposed } \\
\text { to real products incubators' problems } \\
\text { and needs. } \\
\text { - Provides better training. } \\
\text { - Curriculum development assistance. } \\
\text { - Strengthening staff development by } \\
\text { giving faculty members opportunities } \\
\text { to gain practical experience, } \\
\text { identifying new and relevant } \\
\text { programmes. } \\
\text { - Access to industry for both } \\
\text { fundamental and applied research. } \\
\text { - Additional funding through capital } \\
\text { investments by partners. } \\
\text { - Financial rewards of patents and } \\
\text { licenses. } \\
\text { - Access to cutting-edge scientific } \\
\text { equipment. } \\
\text { - Create future employment for } \\
\text { graduates: improve graduates } \\
\text { employability index. } \\
\text { - Joint publications are public relations } \\
\text { tools. } \\
\text { - Offer programmes that are relevant to } \\
\text { industry. } \\
\text { - Amproved return in investment in } \\
\text { contribution to economic } \\
\text { development. } \\
\text { - }\end{array}$ & $\begin{array}{l}\text { - A supply of better qualified } \\
\text { labour } \\
\text { - Obtain access to knowledge } \\
\text { hubs' facilities and expertise } \\
\text { (laboratories, library, professors } \\
\text { and students). } \\
\text { - Obtain a window on Science and } \\
\text { new technology. } \\
\text { - Solve complex operations } \\
\text { problems. } \\
\text { - Obtain prestige or enhanced } \\
\text { image. } \\
\text { - Provide support of technical } \\
\text { excellence. } \\
\text { - Financial rewards of patents and } \\
\text { licenses. } \\
\text { - Stimulate and enhance internal } \\
\text { research and development } \\
\text { programmes. } \\
\text { - Helps scientists identify current } \\
\text { research areas in product design } \\
\text { and development. } \\
\text { - Joint publications are public } \\
\text { relations tools. } \\
\text { - Strengthen research and } \\
\text { development. } \\
\text { - Experience high growth rate. } \\
\text { Technologically sophisticated } \\
\text { high value-added and quality } \\
\text { products. } \\
\text { petter Utilization of human and } \\
\text { physical resources. }\end{array}$ \\
\hline
\end{tabular}

Table 4 shows the benefits that can be harvested by both the knowledge hub and product incubator in a collaboration. The other beneficiary in a collaboration of the knowledge hub and product incubator is the society. The results show that the 
society can benefit from improved return on investment in higher education, more effective educational contribution to economic development, better utilisation of human and physical resources and less social and political stress. The results cover the seven collaboration benefits found by Andrade et al. (2016) and Ankrah and Al-Tabbaa (2015) and the three mutual benefits by Salleh and Omar (2013). The results also concur with the benefits found by Lee (2000) who studied the sustainability of the university and industry research collaboration. The research developed a pragmatic knowledge hub and product incubator collaboration (PKHPIC) framework and presented the results in Figure 5.

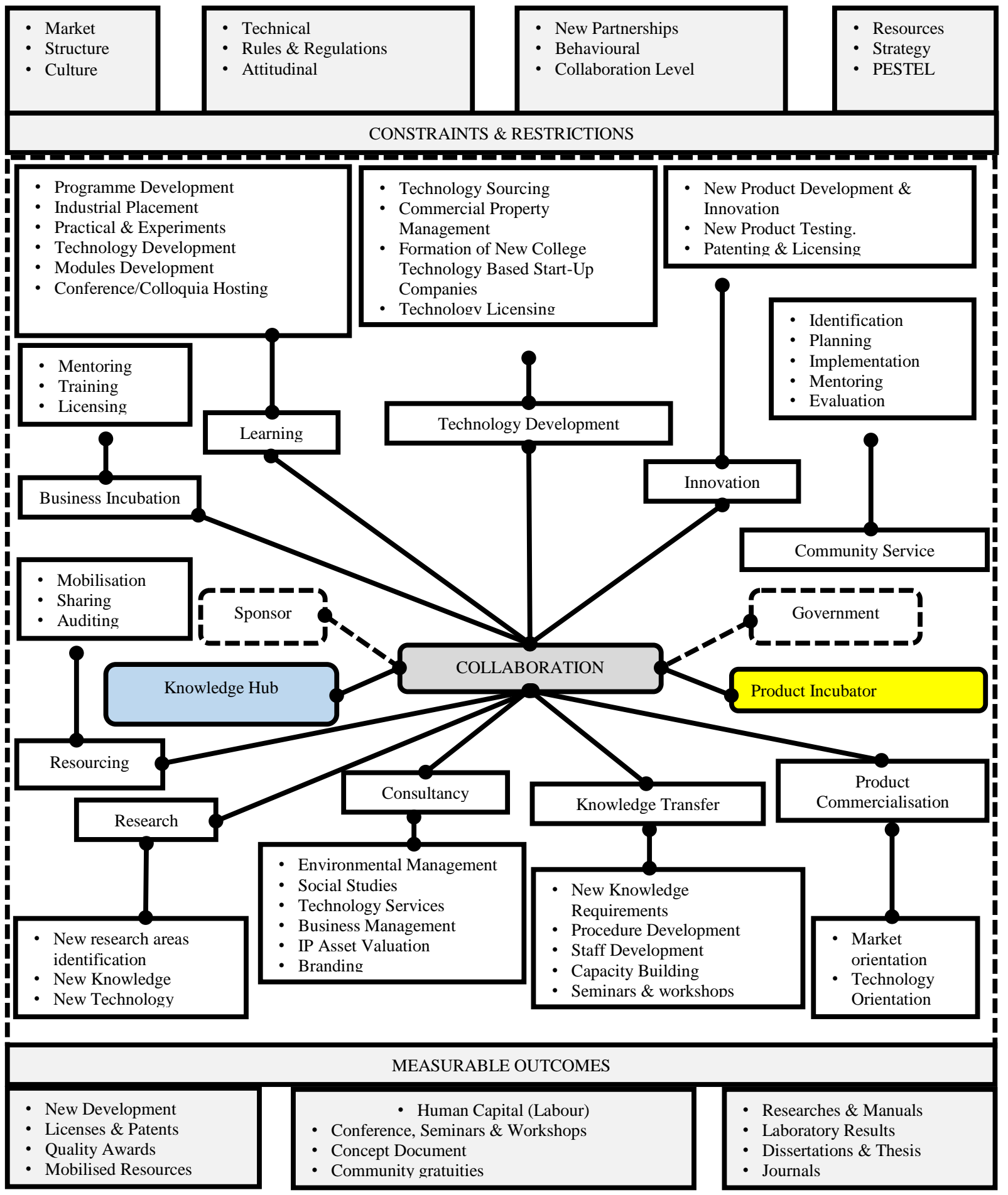

PESTEL = Political, Economic, Social, Technology, Environment \& Legal; IP = Intellectual Property

Figure 5: Pragmatic Knowledge Hub and Product Incubator Collaboration Framework 
Figure 5 shows the main collaboration themes and the related tasks that must be performed. The comprehensive collaboration framework also shows the constraints, monitoring and evaluation parameters that are critical for the successful collaboration between a knowledge hub and a product incubator. The main collaboration themes that are presented in Figure 5 are research, consultancy, knowledge transfer, product commercialisation, innovation, learning, resourcing, technology development, community service and business incubation. Some of the results in Figure 5 have literature background from some of the findings by Ivascu $e t$ al. (2016), Salleh and Omar (2013), Rast et al. (2012), Liew et al. (2012) and Ali (2003).

The PKHPIC framework shows that the collaboration should only be between the knowledge hub and the product incubator with any other institution joining in for benefitting, supporting, monitoring, financing and intermediating. Figure 5 also presents four components of the collaboration between a knowledge hub and a product incubator and these are the team, processes, purpose, resources and constraints. However, the requirements for a successful collaboration include supportive Government policies, collaboration framework and levels, adequate funds and laboratories and young researchers. The collaboration levels (CLs) that can be used during the implementation of the PKHPIC framework that is presented in Figure 5 are:

CL-1, Concept Formulation (1 year): The period of contriving a collaboration idea, plan, explanation, theory or principle into a concept.

CL-2, Prototype Construction ( $1-3$ years): The period of coming up with a prototype of the collaboration objectives. The prototype should bring good impact to improve community's life standard and be potential in new technology based industrial sector.

CL-3, Exploration (3 - 5 years): The period for promoting researches (early discovery of knowledge) that can contribute to increased level of intellectual for the collaborators. The new advance theories and ideas in the strategic niche areas are produced.

CL-4, Fundamental (5 years): The period of exploring new ideas, concepts and theories in the areas of collaboration.

CL-5, Long Term (5 - 20 years): The collaborators generate new ideas and advance theories in areas of collaboration in order to strategically expand the knowledge boundaries.

CL-6, Theme Park (20 years): The period of creating collaboration parks for commercialising tried and tested concepts and theories.

\section{CONCLUSION AND RECOMMENDATIONS}

The research analysed the collaboration forms and areas that can be established between a knowledge hub and a product incubator. The collaboration benefits for the knowledge hub, product incubator and society were identified and examined.
The research discovered the common collaboration themes and the related tasks that should be performed. A pragmatic knowledge hub and product incubator collaboration (PKHPIC) framework was developed. The development could be very useful in establishing a successful and sustainable collaboration between a knowledge hub and a product incubator in Zimbabwe and the whole world. The collaboration themes are the foreseen future ten thematic levels of classifying universities and industries. The adoption of the collaboration thematic approach will mark the beginning of the constitution of the knowledge hub and product incubator parks (KHPIPs) better known as university and industry parks (UIPs). The accreditation and classification of universities will be based on the KHPIP or UIP concept.

\section{ACKNOWLEDGEMENT}

The author wants to thank Mrs A. Tinarwo, Mr T. Masese, CZI Manicaland Executive Chairperson and CZI Manicaland executive members for the good suggestions made during the writing of this research. The article was first presented at the CZI Manicaland executive meeting that was held in March 2019 at Africa University in Mutare, Zimbabwe.

\section{REFERENCES}

[1] Abuja, M., Carapina, T., de Kort, M., Raess, M., Tieken, C., \& Wagstaff, N. (2019). CORBEL Industry collaboration best practice guide. Zenodo. doi:10.5281/zenodo.2615365.svg

[2] Ali, A. (2003). Engaging economic development through the commercialisation of research: the Malaysian experience. General Conference of the Association of Commonwealth Universities. Belfast, Northern Ireland.

[3] Andrade, R., Fernandes, G., \& Tereso, A. (2016). Benefits Management in University-Industry R\&D Collaborative Projects: A Review on Benefits and Success Factors. Procedia Computer Science, 100, $921-927$.

[4] Ankrah, S., \& AL-Tabbaa, O. (2015). Universities - industry collaboration: A systematic review. Scandinavian Journal of Management, 31, 387 - 408.

[5] Awasthy, R., Flint, S., Sankarnarayana, R., \& Jones, L. R. (2020). A framework to improve university-industry collaboration. Journal of Industry-University Collaboration, 2(1), 49-62. doi:10.1108/JIUC-09-2019-0016

[6] Barringer, B., \& Harrison, J. (2000). Walking a tightrope: Creating value through inter-organizational relationships. Journal of Management, 26, $367-403$.

[7] Birchall, D. W., \& Shanaron, J. J. (2006). Business SchoolIndustry Cooperation: Lessons from Case Studies. The XVII ISPIM Conference. Athens: Networks for Innovation.

[8] Bruneel, J., D'esteb, P., \& Salter, A. (2010). Investigating the factors that diminish the barriers to university-industry collaboration. Research Policy, 39, 858 - 868.

[9] Chideme, K. (2019, April 4). Capacity Utilisation seen falling to $30 \%$. Newsday. Retrieved January 9, 2020, from https://www.newsday.co.zw/2019/

[10] DSDL. (2019). Forms and Features of Collaboration: A synthesis for the Collaboration for Wellbeing and Health. United Kingdom: The Health Foundation. Retrieved June 8, 2021, from http://wordpress.collaboratei.com/wp-content/uploads/Forms-andfeatures-of-collaborations.pdf

[11] Enkel, E., Gaddmann, O., \& Cesbrough, W. H. (2009). Open R\&D and Open Innovation: Exploring the Phenomenon. $R \& D$ Management, $39(4), \quad 311 \quad$ - $316 . \quad$ doi:10.1111/j.14679310.2009.00570.x

[12] Freitas, I. M., Marques, R. A., \& Silva, E. M. (2013). Universityindustry collaboration and innovation in emergent and mature 
industries in new industrialized countries. Research Policy, 42, $443-453$.

[13] Fynn, A. (2020, August 4). How to narrow the gap between what universities produce and what employers expect. The Conversation. Retrieved June 7, 2021, from https://theconversation.com/how-to-narrow-the-gap-betweenwhat-universities-produce-and-what-employers-expect-126060

[14] Gann, D., Montresor, F., \& Eisenberg, J. (2018). 3 ways to nurture collaboration between universities and indutry. World Economic Forum. Retrieved June 1, 2020, from https://www.weforum.org/agenda/2018/11/3-ways-to-nurturecollaboration-between-universities-and-industry/

[15] Ivascu, L., Cirjaliu, B., \& Draghici, A. (2016). Business model for the university-industry collaboration in open innovation. $3 r d$ Global Conference on Business, Economics, Management and Tourism. Rome: Elsevier, Procedia Econom.

[16] Kaklauskas, A., Banaitis, A., Ferreira, F. A., Ferreira, J. J., Amaratunga, D., Lepkova, N., . . . Banaitiene, N. (2018). An Evaluation System for University-Industry Partnership Sustainability: Enhancing Options for Entrepreneurial Universities. $\quad$ Sustanability, 10(119), 1 - 17. doi:10.3390/su10010119

[17] König, S. L., \& Ribarić, M. S. (2019). Is There a Mismatch Between Employers' and University Teachers' Perceptions on Graduate Employability in Croatia? Journal of Contemporary Management Issues, 87 - 102. doi:10.30924/mjcmi.24.1.6

[18] Laroui, F. (2020, November 11). Definition and Types of collaboration in business. Retrieved from eXo: https://www.exoplatform.com/blog/2020/11/11/definition-andtypes-of-collaboration-in-business/\#types-of-collaboration

[19] Lee, Y. S. (2000). The Sustainability of University-Industry Research Collaboration: An Empirical Assessment. Journal of Technology Transfer, 25, $111-133$.

[20] Liew, M. S., Tengku Shahdan, T. N., \& Lim, E. S. (2012). Strategic and Tactical Approaches on University - Industry Collaboration. Social and Behavioral Sciences, 56, $405-409$.

[21] Malairaja, C., \& Zawdie, G. (2008). Science parks and universityindustry collaboration in Malaysia . Technology Analysis \& Strategic Management, 20(6), 727-739. doi:DOI: $10.1080 / 09537320802426432$

[22] Marr, A. (2017). Reality Check: Are 90\% of Zimbabweans unemployed? BBC Reality Check. Retrieved October 12, 2019, from http://bbc-news.epizy.com/2017/12/03/reality-check-are-90of-zimbabweans-unemployed/?i=1

[23] Mascarenhas, C., Ferreira, J. J., \& Marques, C. (2018). University-industry cooperation: A systematic literature review and research. Science and Public Policy, 1 - 11. doi:10.1093/scipol/scy003/4829714

[24] McNabb, E. D., \& Swenson, R. C. (2021). Collaboration in Government: Forms and Practices (1st ed.). Routledge.

[25] Morisson, A., \& Pattinson, M. (2020). University-Industry Collaboration. Lille: Interreg Europe Policy Learning Platform.

[26] Moyo, J. (2016). Employment and the Fight against Poverty: Graduates Living in Poverty. Harare: Engagement Global. Retrieved July 11, 2020, from https://www.dandc.eu/en/article/many-university-graduateszimbabwe-are-unemployed

[27] Murairwa, S. (2015). Voluntary Sampling Design. International Journal of Advanced Research in Management and Social Sciences, 4(2), $185 \quad-\quad 200 . \quad$ Retrieved from http://www.garph.co.uk/IJARMSS/Feb2015/18.pdf

[28] Murairwa, S. (2018). Re-engineering the Education Systems: A Continuous Education Quality Improvement Framework. Beau Bassin 71504, Mauritius: LAP Lambert Academic Publishing.

[29] NAP. (2018). Revitalizing the University-Industry-Government Partnership: Creating New Opportunities for the 21st Century Proceedings of a Workshop - in Brief. Washington DC: The National Academic of Science, Engineering \& Medicine. Retrieved from https://www.nap.edu/read/25080/chapter/1

[30] Ncube, L. (2017, March 1). African Universities Churn out useless graduates. Chronicle. Retrieved July 11, 2020, from https://www.chronicle.co.zw/african-universities-churn-outuseless-graduates/

[31] Ngwenya, B. (2018, April 8). Promoting University-Industry collaboration key to economic prosperity in the new political economy. Sunday News. Retrieved June 1, 2020, from https://www.sundaynews.co.zw/promoting-university-industrycollaboration-key-to-economic-prosperity-in-the-new-politicaleconomy/

[32] Nyström, M., Karltun, J., Keller, C., \& Gare, A. B. (2018). Collaborative and partnership research for improvement of health and social services: researcher's experiences from 20 projects. Health Research Policy and Systems, 16(46), 1 - 17. doi:10.1186/s12961-018-0322-0

[33] O'Shea, P. R., Chugh, H., \& Allen, J. T. (2008). Determinants and consequences of university spinoff activity: a conceptual framework. The Journal of Technology Transfer, 33(6), 653 - 666. doi:10.1007/s10961-007-9060-0

[34] Perkmann, M., \& Sobrero, M. (2013). Academic engagement and commercialisation: A review of the literature on university industry relations. Research Policy, 42(2), 423 - 442. doi:10.1016/j.respol.2012.09.007

[35] Perkmann, M., \& Walsh, K. (2019). Relationship-based university-industry links and open innovation: towards a research agenda. London: Figshare. Retrieved from https://hdl.handle.net/2134/2276

[36] Perkmann, M., Tartari, V., Mckelvey, M., Autio, E., Brostrom, A., \& Deste, P. (2013). Academic engagement and commercialisation: A review of the literature on university-industry relations. Research Policy, 42, 423 - 442.

[37] Phan, H. P., \& Siegel, S. D. (2006). The Effectiveness of University Technology Transfer. Now Publishers Inc.

[38] Plewa, C., Korff, N., Johnson, C., Macpherson, G., \& Rampersad, G. (2013). The evolution of university-industry linkages: A framework. Journal of Engineering Technology Management, 30, $21-44$.

[39] Pop, O.-M. (2017, July 18). The Four Main Types of Business Collaboration. Retrieved from HYPE: https://blog.hypeinnovation.com/the-four-main-types-ofcollaboration

[40] Rast, S., Khabiria, N., \& Senina, A. A. (2012). Evaluation Framework for Assessing University-Industry Collaborative Research and Technological Initiative. Social and Behavioral Sciences, 40, $410-416$.

[41] Robert, J. (2019). Mismatch Between Degrees And Jobs. Graduate Employment In Comparative Perspective. ECER 2019. Berlin: European Educational Research Association (EERA). Retrieved from https://eera-ecer.de/ecerprogrammes/conference/24/contribution/47744/

[42] Rothaermel, T. F., Agung, S., \& Jiang, L. (2007). University Entreneurship: A Tazonomy of the Literature. Industrial and Corporate Change, 16(4), 691 - 791. doi:10.1093/icc/dtm023

[43] Rybnicek, R., \& Konigsgruber, R. (2019). What makes industryuniversity collaboration succeed? A systematic review of the literature. Journal of Business Economics, 89, 221 - 250. doi:10.1007/s11573-018-0916-6

[44] Salleha, M. S., \& Omara, M. Z. (2013). University-Industry Collaboration Models in Malaysia. Procedia - Social and Behavioral Sciences, 102, $654-664$.

[45] Scearce, D. (2011). What are the different ways to Collaborate? Grant makers for effective organizations (GEO) and Monitor Institute.

[46] Sherwood, A. L., Butts, S. B., \& Kacar, S. L. (2004). Partnering for Knowledge: A Learning Framework for University - Industry Collaboration. Midwest Academy of Management. Retrieved July 9, 2020, from http://ipadvocatefoundation.org/studies/emory/pdfs/3.1c_partner\% $20 \mathrm{know}$

[47] Shizha, E., \& Kariwo, M. T. (2011). Education and development in Zimbabwe: a social, political and economic analysis. Boston, USA: Sense Publishers. 
[48] Tsitskari, E., Goudas, M., Tsalouchou, E., \& Michalopoulou, M. (2017). Employers' expectations of the employability skills needed in the sport and recreation environment. Journal of Hospitality, Leisure, Sport and Tourism Education, 20(1), 1 - 9. doi:10.1016/j.jhlste.2016.11.002
[49] Zhao, Z., Brostron, A., \& Cai, J. (2020). Promoting Academic Engagement: University Cintext and Individual Characteristics. The Journal of Technology Transfer, 45, 304 - 337. doi:10.1007/s10961-018-9687-z 